\title{
Neurologic aspects of sweating and its disorders
}

Neurology ${ }^{\circledR}$ 2020;94:187. doi:10.1212/WNL.0000000000008730

In the Clinical Implications of Neuroscience Research article "Neurologic aspects of sweating and its disorders" by Minota et al., ${ }^{1}$ the Disclosure should have noted the grant support received from the NIH (R01 NS092625). The authors regret the error.

\section{Reference}

1. Minota K, Coon EA, Benarroch EE. Neurologic aspects of sweating and its disorders. Neurology 2019;92:999-1005.

\section{Outcome of endovascular therapy in stroke with large vessel occlusion and mild symptoms}

Neurology ${ }^{\circledR}$ 2020;94:187. doi:10.1212/WNL.0000000000008829

In the article "Outcome of endovascular therapy in stroke with large vessel occlusion and mild symptoms” by Manno et al., ${ }^{1}$ Dr. Heldner's byline should read Mirjam R. Heldner, MD. The authors regret the error.

\section{Reference}

1. Manno C, Disanto G, Bianco G, et al. Outcome of endovascular therapy in stroke with large vessel occlusion and mild symptoms. Neurology 2019;93:e1618-e1626.

\section{Amyloid and cerebrovascular burden divergently influence brain functional network changes over time}

Neurology ${ }^{\circledR}$ 2020;94:187. doi:10.1212/WNL.0000000000008830

In the article "Amyloid and cerebrovascular burden divergently influence brain functional network changes over time" by Chong et al., ${ }^{1}$ the label beside the blue line in panel A of figure 2 should have read "svMCI PiB-." The authors regret the error.

\section{Reference}

1. Chong JSX, Jang H, Kim HJ, et al. Amyloid and cerebrovascular burden divergently influence brain functional network changes over time. Neurology 2019;93:e1514-e1525.

\section{Child Neurology: Andersen-Tawil syndrome}

Neurology ${ }^{\circledR}$ 2020;94:187. doi:10.1212/WNL.0000000000008828

Two images of patients in the article "Child Neurology: Andersen-Tawil syndrome" by Almuqbil and Srour, ${ }^{1}$ published online March 16, 2015, have been removed because the patients requested that their consent for publication be withdrawn. The removal of the images does not invalidate the paper because an extensive verbal description of the patients was included within the text of the article. The American Academy of Neurology, who owns copyright of the article, the Editor of the journal, and the authors agreed that the images were unnecessary to the message of the paper and agreed to honor the request to remove them.

\section{Reference}

1. Almuqbil M, Srour M. Child Neurology: Andersen-Tawil syndrome. Neurology 2015;84:e78-e80. 


\section{Neurology}

\section{Child Neurology: Andersen-Tawil syndrome \\ Neurology 2020;94;187 Published Online before print December 20, 2019 \\ DOI 10.1212/WNL.0000000000008828}

This information is current as of December 20, 2019

\section{Updated Information \&} Services

References

Permissions \& Licensing

Reprints including high resolution figures, can be found at: http://n.neurology.org/content/94/4/187.4.full

This article cites 1 articles, 1 of which you can access for free at: http://n.neurology.org/content/94/4/187.4.full\#ref-list-1

Information about reproducing this article in parts (figures,tables) or in its entirety can be found online at:

http://www.neurology.org/about/about_the_journal\#permissions

Information about ordering reprints can be found online:

http://n.neurology.org/subscribers/advertise

Neurology ${ }^{\circledR}$ is the official journal of the American Academy of Neurology. Published continuously since 1951, it is now a weekly with 48 issues per year. Copyright (O 2019 American Academy of Neurology. All rights reserved. Print ISSN: 0028-3878. Online ISSN: 1526-632X.

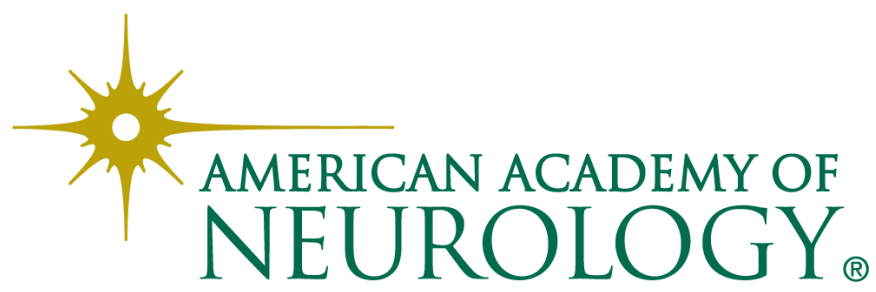

